\title{
SMALL HIVE BEETLE (Aethina tumida Murray), A POTENTIAL THREAT TO BEEKEEPING IN CHILE
}

\author{
Ximena Araneda ${ }^{1}$ Patricia Aldea $^{2 *}$, Ximena Freire $^{1}$ \\ ${ }^{1}$ Departamento de Ciencias Agropecuarias y Acuícolas, Facultad de Recursos Naturales, Universidad \\ Católica de Temuco, Temuco, Chile. https://orcid.org/0000-0002-9583-5611 \\ 2 Corporación Apícola Chile, San Francisco de Mostazal - Región de O’Higgins, Chile. https://orcid. \\ org/0000-0003-2055-7765 \\ *Corresponding author E-mail: plaldea@uc.cl
}

\begin{abstract}
In recent years, beekeeping has been affected by many factors, including pesticides, monoculture and deforestation as well as pests and diseases, which are causing the death of Apis mellifera and other pollinating species. One of the most recent threats is a parasitic beetle of bee colonies, native to sub-Saharan Africa, called small hive beetle (Aethina tumida Murray). It was first detected in the USA in 1996, and it has continued to expand across the American continent. In 2015, it was first discovered in Brazil, being the nearest country to Chile where it has been reported to date. The aim of this work was to carry out a literature review on small hive beetle (SHB) as it can be a potential threat to honey bee colonies in Chile. Adults of Aethina tumida feed on bee eggs while the larvae consume brood, pollen and honey, causing great damage to bee colonies. In addition, they defecate in honey, where a yeast present in their faeces, Kodamaea ohmerique, causes pollen and honey to ferment. Due to the damage it causes and its rapid advance through different continents, its biology and behaviour are being increasingly studied to explore control techniques and risk factors.
\end{abstract}

Key words: small hive beatle, Aethina tumida, plague, honey bees, Apis mellifera, control, parasite.

\section{INTRODUCTION}

In Chile, as in other countries around the world, the honey bee (Apis mellifera) is one of the main pollinating agents. Honey bees were originally imported for the commercial production of honey, wax, propolis, queens, etc. (FAO, 2017).

Chilean honey exports fell markedly between 2015 and 2017, from 9,888 tons in 2015 to 7,136 tons in 2016, and 5,212 tons in 2017 (ODEPA, 2018), recording the lowest export volume in the last 12 years. However, the production of queens and bee colonies, together with pollination services have had a great growth (SAG, 2019).

Various authors have reported that honey bees have been dying almost inexplicably in recent years, mainly in the Northern Hemisphere. The reasons for this mortality are many and interdependent, including parasitic diseases, pesticide applications, and large areas of monocultures (Ortiz, 2014).

According to Merida and Arnold (2016), bees have their own diseases and parasites that weaken and frequently kill them. Most of these parasites and diseases are invasive species that bees cannot combat by natural adaptation or by developing immunity. Sick or parasite-infested bees may in turn be more vulnerable to other factors, such as poor nutrition or exposure to chemical or toxic substances (Merida and Arnold, 2016).

The World Organization of Animal Health (OIE, 2016) described the small hive beetle (Aethina tumida Murray) (Coleoptera: Nitidulidae) as a new pest.

The small hive beetle (SHB) is a parasite of bee colonies originating from sub-Saharan Africa.

Received: 10 July 2020. Accepted: 28 November 2020. 
This insect has spread across the world, reaching the United States in 1996 and Brazil in 2015 (Toufailia et al., 2017). According to the official records available from the OIE, the current state of this pest in Brazil is "Infection/infestation limited to one or more zones". Its presence in Brazil represents a proximity threat to Chile, where beekeepers and authorities are expressing a growing concern about this parasite as it affects bee production resulting in big economic losses. Its management under South American conditions is unknown. As it has spread very rapidly, SHB, Aethina tumida, is being studied with increasing frequency, for both its biological and economic importance (Hernández et al., 2014).

Various studies have been carried out in countries where the presence of SHB has been reported. In Chile, there is still no evidence of this pest (OIE, 2019), but its arrival may be imminent, being a potential threat to honey bee colonies in the country. Therefore, the objective of this work was to collect information on the biological and behavioural characteristics of the SHB as early detection, reporting and monitoring of this pest may help mitigate its establishment.

\section{Description and characteristics of $A$. tumida}

The small hive beetle (SHB) was first described by Murray in 1867, and as a parasite of A. mellifera capensis in 1940 by A. Lundie (MAGRAMA, 2016). It lives and reproduces inside beehives (Delaplane, 1998; Saldaña-Loza et al., 2014).

The eggs, larvae and adults of SHB can survive in the hive, feeding on hive products as well as brood stages of bees. The mature larvae leave the hive and go underground, almost always close to the hive, to complete their metamorphosis. Then as adults they fly back into the hive (MAGRAMA, 2016).

The eggs of SHB are creamy white in colour, $1.4 \mathrm{~mm}$ long and $0.26 \mathrm{~mm}$ wide. They are smaller than bee eggs and are typically found in racimes. The eggs hatch after 3 to 6 days, and the larvae emerge; they require a hive temperature between $28^{\circ} \mathrm{C}$ and $32^{\circ} \mathrm{C}$ and humidity higher than $50 \%$ (De Guzman and Frake, 2007). The females lay their eggs in dark cracks or cavities in the hive. Cracks play an important part in protecting the eggs until they hatch because bees cannot eliminate them (Neumann and Härtel, 2004).

SHB females can easily lay as many as 2000 eggs in their lives, but the normal number is around 1000 eggs over a period of 3 to 4 months, with a survival rate of around 50\% (Saldaña-Loza et al., 2014). They lay eggs hidden behind the operculum of sealed cells containing a bee larva or pupa, making it difficult for the nurse bees to detect them. In some cases, however, bees can detect this activity and respond by eliminating the operculum and contents of the cells (highly hygienic behaviour), but this behaviour is not present in all genetic lines of honey bees (De Guzman et al., 2008; Ellis and Delaplane, 2008).

The SHB larvae are creamy yellow in colour, 10 to $11 \mathrm{~mm}$ long and $3 \mathrm{~mm}$ wide. They take 10 to 14 days to develop. When the larvae have developed sufficiently, they start to leave the food source in search of a good place to pupate. If the soil is not suitable, the larva can travel as far as $100 \mathrm{~m}$ to find ideal conditions to continue its metamorphosis. It is important to note that SHB larvae are similar to those of the wax moth (Galleria mellonella) and, consequently, correct identification is important (Saldaña-Loza et al., 2014).

For its transformation into a pupa, the SHB larva needs to find soft or easily-worked soil in which to bury itself; it digs down 2 to $20 \mathrm{~cm}$ and forms a pupation capsule with soil and its own excretions (De Guzman et al., 2009). The pupae are pearly white when new, turning darker as they mature. This phase in the ground lasts from 15 to 74 days, and if the environmental humidity and temperature are not favourable, the pupae can survive up to 100 days before they emerge (De Guzman and Frake 2007; Saldaña-Loza et al., 2014).

The development time from egg-laying to adult can vary between 38 and 81 days, depending on environmental conditions. The adults avoid light and take refuge between the honeycombs and at the bottom of the hive, but the larvae are found both at the bottom of the hive and on the frames. It appears that the SHB is only active in summer, when it can produce up to five generations (MAGRAMA, 2016).

The mature adults are dark brown to black in colour, while the young adults are pale brown; they measure 5 to $7 \mathrm{~mm}$ in length and 3 to $4.5 \mathrm{~mm}$ in width. They can live up to 6 months, depending on food sources. The higher the protein value of their food, the more they reproduce (SaldañaLoza et al., 2014).

The SHB can develop successfully in various soil types, and the vertical movement of the larvae is affected by humidity (De Guzmán et al., 2009).

The development, body size and weight of the SHB are temperature-dependent. Thus, the abundance and impact of the small hive beetle in bee colonies can be influenced by different thermal conditions (De Guzmán and Frake, 2007).

The principal stimuli that guide the SHB to the colony are the smell of the adult bees, brood stages, pollen and honey. Tests have also been carried out of the visual stimuli of colour, in which white was found to be more attractive than black, and of height, because the beetle goes to 
the highest parts of the hives (De Guzman et al., 2011).

SHB infestations are inoffensive when the colonies are well established, but not when they are only nucs (Mustafa et al., 2013).

In Cape bee honeycombs (A. mellifera capensis Esch.), theSHB has shown capable of perforating the sides of empty cells and lay under the pupae in adjacent cells. However, bees can detect this and eliminate all the infested young (hygienic behaviour), even when they are so well disguised (Ellis et al., 2003). Some studies have described that when beetles enter a bee colony, a group of guardian bees confines them to the edge of the nest, a response which limits the beetle's reproduction (Ellis, 2015).

According to Halcroft et al.(2011), the SHB is a parasite of colonies of social bees and has become an invasive species, increasing concern about the potential threat to native pollinators. Neumann et al. (2016) indicated that A. tumida reproduces in association with bees, bumblebees (Bombus impatiens) and stingless bees (Tetragonula carbonaria, Dactylurina staudingeri, between others), but also in fruit and decomposing meat. Defensive behaviour strategies to SHB have been recorded in the Australian stingless bee, Austroplebeia australis Friese (Halcroft et al., 2011). According to Greco et al. (2010), a particular defense mechanism was observed in the Australian species Trigona carbonaria, consisting in the capture and mummification of the beetles using a mixture of resins, wax and mud. This prevents the advance of the beetle and eliminates its ability to reproduce.

The vulnerability of bumblebee colonies (Bombus impatiens) has been known for over a decade, since they can be potential hosts to the SHB, which invades the colonies and lays there easily (Hoffmann et al., 2008).

\section{Geographical distribution}

The SHB is an important pest in America and Australia, and an emerging threat in Europe (Tarver et al., 2016), having spread rapidly to three continents. It may continue to advance into other countries around the world, particularly because its means of propagation or introduction have not yet been fully identified (Hood, 2015). According to MAGRAMA (2016), since the SHB first appeared in USA in 1996, its expansion across the continent has not stopped.. Since 2000, the SHB has spread within Africa, and to Australia, Europe and North and Central America, reaching Costa Rica and Brazil in 2015 (Lóriga et al., 2014; Mutinelli et al., 2014; Umaña et al., 2014; Ramírez and Calderón, 2018). According to Toufailia et al. (2017), the first beetles were found in a hive of $A$. mellifera in Piracicaba, São Paulo State, Brazil, in March 2015. This report of the pest in A. mellifera is the first in South America and is still current in 2019 (OIE, 2019).

In Korea, only four species of the sub-genus Aethina erichson were known, but there are now two species new to Korea: Aethina aeneipennis, and A. tumida. This is the first report of SHB in Far Eastern Asia. SHB has invaded different parts of the world, representing a real threat for beekeeping as a parasite and carrion-eating pest. It seldom causes damage in its place of origin. However, its economic impact on the beekeeping industry in other countries where it has been introduced has been significant (Cuthbertson et al., 2013; Lee et al., 2017).

Chile's Agricultural and Animal Production Service (SAG) has declared the country to be free of Africanization, SHB (A. tumida) and Asiatic acariosis (Tropilaelaps clareae). To conserve this condition, it has drawn up a prevention plan which involves distributing didactic material to familiarize Chilean beekeepers with the characteristics of this pest in order to allow early detection and reporting. If A. tumida is found to be present in future, control measures will be put in place (Gallardo, 2017). Being "SHB free" allows Chile to export honey and biological material (queens, bee nuclei) to foreign markets, which is a comparative advantage of the Chilean beekeeping industry (PROCHILE, 2018).

\section{Characteristics of the damage}

SHB damage to bee colonies is direct because adult beetles eat bee eggs while their larvae consume brood stages, pollen and honey and do severe damage to wax combs (Calderón et al., 2006; Pirk and Neumann, 2013), opening tunnels through the combs and killing brood stages. This leads bees to abandon the infested combs (Meikle et al., 2012). Furthermore, as beetles defecate in the honey, they contaminate it with the yeast Kodamaea ohmeri, which causes it to ferment (Valdovinos-Flores et al., 2016). Contaminated honey cannot be sold and is unpleasant to the bees. As it cannot be used to feed them, the negative effect on the beekeeper's income is exacerbated (Meikle et al., 2012). Furthermore, Valdovinos-Flores et al. (2016) have reported that SHB releases compounds into the honey that act as aggregation pheromones, attracting more individuals to the infested hive and worsening its condition.

Colonies of dead bees or abandoned combs present high levels of infestation. Consequently, methods for reducing SHB populations, like eliminating dead colonies (Neumann et al., 2018) and preventing the SHB from reproducing in 
honey extraction rooms, are important strategies for controlling this pest once it becomes established (Spiewok et al., 2007).

The main dispersion route of SHB is by flight (it can fly more than $10 \mathrm{~km}$ ) and is favoured by transhumance. The eggs may also adhere to bees as a secondary means of dispersion (MAGRAMA, 2016). In Chile, the movement of bee colonies throughout the country, either by migration in search of nectar flows or for pollination services, would be a strong factor in favour of $\mathrm{SHB}$ dispersion. According to the records of the SAG website (SIPEC), almost $60 \%$ of the declared colonies at the end of 2018 moved within the country in such way (SAG, 2019).

The main economic impacts to the beekeeping industry are related to the time and work required to detect and control beetles, honey production losses and deterioration, and the reduction of pollination services (Calderón et al., 2006).

Finally, the SHB can be a vector of various pathogens. In fact, Eyer et al. (2009) described it as a potential biological vector of various viruses affecting $A$. mellifera. Furthermore, a study on the infection of $N$. ceranae in SHB conducted in 2017 found that $N$. ceranae was present in seven out of 10 samples of $\mathrm{SHB}$, showing that microspores can be transmitted mechanically by the beetle. This was the first report of infection by N. ceranae in A. tumida (Cilia et al., 2018). Although there are no scientific records of an association between SHB and other pathogens to date, it seems that it is at the very least a stress factor which makes colonies more vulnerable to pathogen attack.

European bees have proven much more susceptible and much less effective in combating this pest than colonies of African subspecies (Hernández et al., 2014, Neumann et al., 2018). Beekeepers, veterinarians, producers, and distributors who work with $A$. mellifera must be aware of and informed about the threat posed by A. tumida to honey bees (Mutinelli et al., 2014).

\section{Control methods}

Laboratory experiments have been carried out to identify SHB attractants, either as a food source or to lay their eggs in. To date, it has been shown that adult SHB can also feed and lay eggs in fruit and decomposing meat, even in the presence of hive products. Thus, in laboratory conditions SHB can reproduce on mangoes, bananas, and grapes, but with a lower laying rate than on pollen and honey (Buchholz et al., 2008).

In the search for alternatives for managing A. tumida, in order to replace chemical control by organic products, a study was carried out into a fungal pathogen [Metarhizium anisopliae (Metschnikoff) variety Sorokin, variety anisopliae
FI-203]. The adult beetles were susceptible to this fungus and to three other generalist entomopathogenic fungi isolated [M. anisopliae, Beauveria bassiana (Balsamo) Vuillemin, and Hirsutella illustris Minter \& Brady]; the results showed that entomopathogenic fungi are an alternative for controlling SHB (Muerrle et al., 2006). In the UK, the nematodes Steinernema kraussei and S. carpocapsae provide excellent control with $100 \%$ mortality of the larvae. Sequential application of the nematodes in larvae that then pupate provides control for a maximum of 3 weeks. This is relevant information for the control of A. tumida (Cuthbertson et al., 2012). Other entomopathogenic nematodes like Heterorhabditis have the potential to be effective controllers of SHB. According to Hill et al. (2015), there are certain soil conditions - such as humidity, temperature, exposure to sunshine and plant cover - which favour the effectiveness of Heterorhabditis, allowing it to reduce populations of A. tumida in A. mellifera colonies. Ellis et al. (2010) suggested that the use of entomopathogenic nematodes may be part of an integrated pest management strategy to reduce SHB populations in bee colonies to tolerable levels.

There are other species which can help to combat SHB. Donovan and Paul (2005) suggested that pseudoscorpions (Ellingsenius fulleri and E. indicus) can protect bees from pests like the small hive beetle. Torto et al. (2010) reported that the ant Pheidole megacephala was a key predator of SHB larvae in a site in Kenya.

In a trial using light traps, the response of adult SHB and larvae to different wavelengths of the light spectrum was tested. The trials showed that when a light source was placed in the traps, 10 times more adult beetles and 20 times more larvae were captured than in a trap without light. Thus, using these traps in places where honey is extracted or stored may be a promising alternative for controlling SHB (Duehl et al., 2012).

In the search for alternatives for controlling $A$. tumida, Valdovinos-Flores et al. (2016) proposed a trap, which uses boric acid and an attractant, known as the BAA trap. The attractant that uses this trap mimics the fermentation process caused by Kodamaea ohmeri in the hive. The use of this trap has no residual effect on the honey or wax, i.e., there is no significant difference in the boron content before and after treatment. Saldaña-Loza et al. (2014) described the BAA trap as a narrow case with orifices in the sides, which allow the beetle to enter and eat the bait, but do not permit entry of bees. This system has proven $90 \%$ effective against SHB (Reyes-Escobar et al., 2016).

Nolan and Hood (2008) evaluated two attractants, one based on the yeast Kodamaea 
ohmeri $(56.2 \%)$ and one on cider vinegar (43.3\%). Both increased SHB capture compared with the control traps $(0.3 \%)$. The yeast-based attractant presented increased effectiveness in SHB capture during the hottest months. There were more operculated juveniles and fewer beetles in colonies with traps baited with attractant than in those with control traps containing neither attractant nor mineral oil.

De Guzmán et al. (2008) compared the ability of different subspecies of honeybees to eliminate SHB. They compared Russian bees and a commercial stock (predominantly A. m. ligustica), evaluating their ability to detect $A$. tumida eggs. The results showed that both races of bees were able to detect eggs in cells with an operculated juvenile and eliminate them from the infested cell. Neumann and Härtel (2004) indicated that African colonies eliminate both eggs and larvae of the SHB without protection in short periods of time. This elimination behaviour plays an important role in the apparent resistance of African bees to infestations of this beetle. African bees present other behaviours, such as their greater efficiency in preparing the colony to abandon the nest when infested by SHB; this reduces their vulnerability compared to European bees (Neumann et al., 2018).

Reducing the size of the hive entrance to diminish invasion by adult beetles may also be an alternative worth considering and evaluating (Ellis et al., 2002).

The ability of $A$. mellifera bees to face up to diseases and parasites depends on a variety of factors, like their nutritional state and immunological condition, exposure to pesticides and unfavourable environmental changes. In the case of SHB, other factors are involved, such as hygienic behaviour (Ellis et al., 2003), the ability to isolate or marginalise SHB infestation in the colony (Ellis, 2015), and the ability to abandon the nest without leaving excessive quantities of combs with food or larvae, which could serve as a resource for SHB reproduction (Neumann et al., 2018). Transhumance, colony movement for pollination services, sale of biological material, extraction rooms and keeping dead colonies in the apiary or in stores where they will attract $\mathrm{SHB}$, are all conditions that facilitate dispersion and settlement of this pest.

\section{CONCLUSIONS}

Early detection and control measures to help prevent the establishment of small hive beetle (SHB) involve constant monitoring (e.g., use of entomopathogens, use of traps (either light or $\mathrm{BAA})$, and search for genetic lines of bees with resistance and defence mechanisms), and learning about possible natural enemies to this pest in the immediate surroundings of an apiary. In this sense, further research is required to deepen knowledge of the behaviour of this beetle in the different environments colonized, and of the factors that might favour colonization or make bees more susceptible.

To date, the ecological/cultural factors or production practices favouring the establishment of this pest in Chile are still unknown, but some risk factors can be inferred. Although SAG has introduced monitoring measures, joint work with beekeepers is required for effective monitoring to ensure early detection and reporting of SHB in Chilean apiaries.

If Chile were to lose its "SHB free" condition, it would run the risk of being excluded from its export markets for biological material, meaning loss of an income source for beekeepers. Agriculture would also be affected, as infestation with this parasite would reduce the pollination capacity of affected colonies.

\section{LITERATURE CITED}

Buchholz. S., M.O. Schäfer, S. Spiewok, J.S. Pettis, M. Duncan, W. Ritter, et al. 2008. Alternative food sources of Aethina tumida (Coleoptera: Nitidulidae). J. Apicult. Res. Bee World 47(3):200-209.

Calderón, R.A., H. Arce, and J.F. Ramírez. 2006. The small hive beetle Aethina tumida Murray, an important problem affecting honey bees. Cienc. Vet. 24(1):49-55.

Cilia. G., I. Cardaio, P.E. Jarmela dos Santos, J. Ellis, and A. Nanetti. 2018. The first detection of Nosema ceranae (Microsporidia) in the small hive beetle, Aethina tumida Murray (Coleoptera: Nitidulidae). Apidologie 49: 619-624.

Cuthbertson, A.G.S., J.J. Mathers, L.F. Blackburn, M.E. Powell, G. Marris, S. Pietravalle, et al. 2012. Screening commercially available entomopathogenic biocontrol agents for the control of Aethina tumida (Coleoptera: Nitidulidae) in the UK. Insects 3(3):719-726.

Cuthbertson, A.G.S., M.E. Wakefield, M.E. Powell, G. Marris, H. Anderson, G.E. Budge, et al. 2013. The small hive beetle Aethina tumida: A review of its biology and control measures. Curr. Zool. 59(5):644-653.

De Guzman L.I., A.M. Frake, T.E. Rinderer, and R.T. Arbogast. 2011. Effect of height and color on the efficiency of pole traps for Aethina tumida (Coleoptera: Nitidulidae). J. Econ. Entomol. 104(1):26-31. 
De Guzman L.I., J.A. Prudente, T.E. Rinderer, A.M. Frake, and H. Tubbs. 2009. Population of small hive beetles (Aethina tumida Murray) in two apiaries having different soil textures in Mississippi. Sci. Bee. Cult. 1(1):4-8.

De Guzman L.I., A.M. Frake, and T.E. Rinderer. 2008. Detection and removal of brood infested with eggs and larvae of small hive beetles (Aethina tumida Murray) by Russian honeybees. J. Apicult. Res. 47(3):216-221.

De Guzman L.I., and A.M. Frake. 2007. Temperature affects Aethina tumida (Coleoptera: Nitidulidae) development. J. Apicult. Res. 46(2):88-93.

Delaplane, K.S. 1998. The small hive beetle, Aethina tumida. A new beekeeping pest. University of Georgia, Tifton, Georgia, USA.

Donovan, B.J., and F. Paul. 2005. Pseudoscorpions: the forgotten beneficials inside beehives and their potential for management for control of varroa and other arthropod pests. Bee World 86(4):83-87.

Duehl, A.J., R.T. Arbogast, A.B. Sheridan, and P.E. Teal. 2012. The influence of light on small hive beetle (Aethina tumida) behavior and trap capture. Apidologie 43:417-424.

Ellis, J.D. 2015. Reviewing the confinement of small hive beetles (Aethina tumida) by western honeybees (Apis mellifera). Bee World 86(3):55-62.

Ellis, J.D., K.S. Delaplane, R. Hepburn, and P.J. Elzen. 2002. Controlling small hive beetles (Aethina tumida Murray) in honeybee (Apis mellifera) colonies using a modified hive entrance. Am. Bee J. 142(4):288-290.

Ellis, J.D., and K.S. Delaplane. 2008. Small hive beetle (Aethina tumida) oviposition behaviour in sealed brood cells with notes on the removal of the cell contents by European honeybees (Apis mellifera). J. Apicult. Res. 47(3):210-215.

Ellis, J.D., C.S. Richards, H.R. Hepburn, and P. Elzen. 2003. Ovoposition by small hive beetles elicits hygienic responses from Cape honeybees. Sci. Nat. 90(11):532-535.

Ellis, J.D., S. Spiewok, K.S. Delaplane, S. Buchholz, P. Neumann, and W.L. Tedders. 2010. Susceptibility of Aethina tumida (Coleoptera: Nitidulidae) larvae and pupae to entomopathogenic nematodes. J. Econ. Entomol. 103(1):1-9.

Eyer, M., Y.P. Chen, M.O. Schäfer, J. Pettis, and P. Neumann. 2009. Small hive beetle, Aethina tumida, as a potential biological vector of honeybee viruses. Apidologie 40:419-428.
FAO. 2017. Estado del arte del servicio ecosistémico de la polinización en Chile, Paraguay y Perú. Organización de las Naciones Unidas para la Alimentación y la Agricultura (FAO), Santiago, Chile.

Gallardo, M. 2017. Situación sanitaria apícola. Servicio Agrícola y Ganadero (SAG), División Protección Pecuaria, Santiago, Chile.

Greco, M.K., D. Hoffmann, A. Dollin, M. Duncan, R. Spooner-Hart, and P. Neumann. 2010. The alternative Pharaoh approach: stingless bees mummify beetle parasites alive. Sci. Nat. 97(3):319-323.

Halcroft, M., R. Spooner-Hart, and P. Neumann. 2011. Behavioral defense strategies of the stingless bee, Austroplebeia australis, against the small hive beetle, Aethina tumida. Insect Soc. 58(2):245-253.

Hernández, C.A., B.J. Loredo, J.A. Adame, and D.G. López. 2014. Situación actual y perspectivas de distribución, crecimiento y control del pequeño escarabajo de la colmena (Aethina tumida) en México. Apiciencia 16(1):40-52.

Hill, E.S., A.B. Smythe, and D.A. Delaney. 2015. Assessing the role of environmental conditions on efficacy rates of Heterorhabditis indica (Nematoda: Heterorhabditidae) for controlling Aethina tumida (Coleoptera: Nitidulidae) in honeybee (Hymenoptera: Apidae) colonies: a citizen science approach. J. Econom. Entomol. 109(1):1-7.

Hoffmann, D., J.S. Pettis, and P. Neumann. 2008. Potential host shift of the small hive beetle (Aethina tumida) to bumblebee colonies (Bombus impatiens). Insect Soc. 55:153-162.

Hood, W.M. 2015. The small hive beetle, Aethina tumida: A review. Bee World 85(3):51-59.

Lee, S., K. Hong, Y.S. Cho, Y.S. Choi, M. Yoo, and S. Lee. 2017. Review of the subgenus Aethina Erichson s. str. (Coleoptera: Nitidulidae: Nitidulinae) in Korea, reporting recent invasion of small hive beetle, Aethina tumida. J. Asia-Pac. Entomol. 20(2):553-558.

Lóriga, W., L. Fonte, and J. Demedio. 2014. Reporte de Aethina tumida Murray (Coleoptera, Nitidulidae) en colonias de la abeja sin aguijón Melipona beecheii Bennett de Matanzas y Mayabeque. Rev. Salud Anim. 36(3):201-204.

MAGRAMA. 2016. Manual práctico de operaciones en la lucha contra Aethina tumida y Tropilaelaps spp. Sección 3: Breve reseña de las enfermedades. Ministerio de Agricultura, Alimentación y Medio Ambiente, España. 
Meikle, W.G., J.M. Patt, and D. Sammataro. 2012. Intraspecific competition effects on Aethina tumida (Coleoptera: Nitidulidae). J. Econ. Entomol. 105(1):26-33.

Merida, J., and N. Arnold. 2016. Diversidad de abejas. Suplemento Científico de La Jornada Veracruz 6(65):2.

Muerrle, T.M., P. Neumann, J. Dames, H.R. Hepburn, and M.P. Hill. 2006. Susceptibility of adult Aethina tumida (Coleoptera: Nitidulidae) to entomopathogenic fungi. J. Econ. Entomol. 99(1):1-6.

Mustafa, S.G., S. Spiewok, M. Duncan, R. SpoonerHart, and P. Rosenkranz. 2013. Susceptibility of small honeybee colonies to invasion by the small hive beetle, Aethina tumida (Coleoptera, Nitidulidae). J. Appl. Entomol. 138(7):1-4.

Mutinelli, F., F. Montarsi, G. Federico, A. Granato, A. Maroni, G. Grandinetti, et al. 2014. Detection of Aethina tumida Murray (Coleoptera: Nitidulidae.) in Italy: outbreaks and early reaction measures. J. Apicult. Res. 53(5):569-575.

Neumann, P., and S. Härtel. 2004. Removal of small hive beetle (Aethina tumida) eggs and larvae by African honeybee colonies (Apis mellifera scutellata). Apidologie 35:31-36.

Neumann, P., J.S. Pettis, and M.O. Schäffer. 2016. Quo vadis Aethina tumida? Biology and control of small hive beetles. Apidologie 47(3):4-43.

Neumann, P., S. Spiewok, J. Pettis, S. Radloff, R. Spooner-Hart, and R. Hepburn. 2018. Differences in absconding between African and European honeybee subspecies facilitate invasion success of small hive beetles. Apidologie 49:527-537.

Nolan, M.P., and W.M. Hood. 2008. Comparison of two attractants to small hive beetles, Aethina tumida, in honey bee colonies. J. Apicult. Res. Bee World 47(3):229-233.

ODEPA. 2018. Apicultura chilena: actualización de mercado y estadísticas sectoriales. Ministerio de Agricultura, Oficina de Estudios y Políticas Agrarias (ODEPA), Santiago, Chile.

OIE. 2016. Plan de contingencia para la infestación por el pequeño escarabajo de las colmenas (PEC) en Ecuador. Ministerio de Agricultura, Ganadería, Acuicultura y Pesca. Agrocalidad: agencia ecuatoriana de aseguramiento de la calidad del agro, Quito, Ecuador.

OIE. 2019. List of countries by disease situation. Available at https://www.oie.int/wahis_2/ public/wahid.php/Diseaseinformation/ statuslist. (Accessed 01 July 2019).
Ortiz, M. 2014. La primavera gris. Sobre el declive de las abejas. Revista Vasca de Administración Pública 99:2261-2287.

Pirk, C.W.W., and P. Neumann. .2013. Small hive beetles are facultative predators of adult honey bees. J. Insect. Behav. 26:796-803.

PROCHILE. 2018. PMP Estudio de mercado apícola en Canadá. Oficina Comercial de Chile, ProChile, Toronto, Canadá.

Ramírez, M., and R. Calderón. 2018. Situación del pequeño escarabajo, Aethina tumida, en colmenas de abejas africanizadas (Apis mellifera) en Costa Rica: Muestreo de apiarios 2014-2017. Rev. Ciencias Veterinarias 36(1):19-26.

Reyes-Escobar, O., E. Dosal-Alonso, C. LaraAlvarez, L.G. Lara-Alvarez, J.A. DorantesUgalde, and L.M. Saldaña-Loza. 2016. Lethal effect of boric acid and attractants against the small hive beetle, Aethina tumida Murray (Coleoptera: Nitidulidae). J. Apicult. Res. 54(3):1-7.

Saldaña-Loza, L.M., L.G. Lara, and J.A. Dorantes. 2014. Manual de nuevos manejos en la apicultura para el pequeño escarabajo de la colmena Aethina tumida Murray. 2da ed. Servicios Apícolas de Querétaro y SAGARPA, México.

SAG. 2019. Boletín apícola $\mathrm{N}^{\circ}$ 4, marzo 2019. Servicio Agrícola y Ganadero (SAG), División de Protección Pecuaria, Santiago, Chile.

Spiewok, S., J.S. Pettis, M. Duncan, R. SpoonerHart, D. Westervelt, and P. Neumann. 2007. Small hive beetle, Aethina tumida, populations I: Infestation levels of honeybee colonies, apiaries and regions. Apidologie 38:595-605.

Tarver, M.R., Q. Huang, L. De Guzman, T. Rinderer, B. Holloway, J. Reese, et al. 2016. Transcriptomic and functional resources for the small hive beetle Aethina tumida, a worldwide parasite of honey bees. Genom. Data 9:97-99.

Torto, B., A. Fombong, R.T. Arbogast, and P.E.A. Teal. 2010. Monitoring Aethina tumida (Coleoptera: Nitidulidae) with baited bottom board traps: occurrence and seasonal abundance in honey bee colonies in Kenya. Environ. Entomol. 39(6):1731-1736.

Toufailia, H.A., D.A. Alves, D.C. Bená, J.M.S. Bento, N.S.A. Iwanicki, A.R. Cline, et al. 2017. First record of small hive beetle, Aethina tumida Murray, in South America. J. Apicult. Res. 56(1):76-80. 
Umaña, C., A. Cubero, B. León, and G. Chaves. 2014. Determinación de la presencia / ausencia del pequeño escarabajo de la colmena (Aethina tumida Murray) en las explotaciones apícolas Apis mellifera scutellata de Costa Rica. Rev. Ciencias Veterinarias 32(2):47-55.

Valdovinos-Flores, C., O. Gaspar-Ramírez, M.E. Heras-Ramirez, C. Lara-Álvarez, J.A. Donantes-Ugalde, and L.M. Saldaña-Loza. 2016. Boron and coumaphos residues in hive materials following treatments for the control of Aethina tumida Murray. PLoS One 11(4):1-11. 